\title{
Microcystin-LR equivalent concentrations in fish tissue during a post- bloom Microcystis exposure in Loskop Dam, South Africa
}

\author{
T Nchabeleng', P Cheng'2, PJ Oberholster ${ }^{2,3}$, A-M Botha ${ }^{4}$, WJ Smit ${ }^{1}$ and WJ Luus-Powell ${ }^{1 *}$ \\ ${ }^{1}$ Department of Biodiversity, School of Molecular and Life Sciences, University of Limpopo, Sovenga, South Africa \\ ${ }^{2}$ CSIR Natural Resources and the Environment, Stellenbosch, South Africa \\ ${ }^{3}$ Department of Paraclinical Sciences, Faculty of Veterinary Science, University of Pretoria, Onderstepoort, South Africa \\ ${ }^{4}$ Department of Genetics, University of Stellenbosch, Stellenbosch, South Africa \\ * Corresponding author, e-mail: wilmien.powell@ul.ac.za
}

\begin{abstract}
The effects of a decomposing cyanobacteria bloom on water quality and the accumulation of microcystin-LR equivalent toxin in fish at Loskop Dam were studied in May 2012. Enzyme-linked immunosorbent assay [ELISA] was used to confirm the presence of microcystin-LR equivalent in the water and to determine the microcystin (MCYST) concentration in the liver and muscle of fish. The lowest concentration of extracellular MCYST-LR equivalent was recorded in the lacustrine zone, where no cyanobacterial cells were observed, while the highest concentration $\left(3.25 \mu \mathrm{g} \mathrm{I}^{-1}\right), 3.25 \times$ higher than World Health Organization standard, was

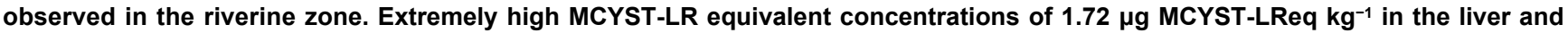
$0.19 \mu \mathrm{g} \mathrm{kg}^{-1}$ in muscles of Labeo rosae, and $2.14 \mu \mathrm{g}$ MCYST-LReq $\mathrm{kg}^{-1}$ in the liver and $0.17 \mu \mathrm{g} \mathrm{kg}{ }^{-1}$ in muscles of Oreochromis mossambicus, indicate that the consumption of sufficient fish biomass might cause severe adverse effects in humans. Microscopic analyses of the stomach content of both fish species revealed low numbers of cyanobacterial Microcystis aeruginosa cells in comparison to other phytoplankton. The extracellular MCYST-LR equivalent of the decomposing bloom may have played a major role in the high levels observed in the livers of the two fish species. These findings are important for all downstream water users.
\end{abstract}

Keywords: cyanobacteria, indigenous fish species, Labeo rosae, liver, muscle tissue, Oreochromis mossambicus

Introduction

Blooms of cyanobacteria alter environmental and economic activities, resulting in a decrease in property values and loss in ecotourism (Oberholster 2009). The cyanotoxin produced by cyanobacteria can affect animals, fish and humans in different ways, depending on the type of toxin. For instance, the potent microcystins (MCYSTs), which are hepatotoxins, may cause liver damage and/or promote tumour growth in animals and humans through inhibition of protein phosphatase 1 and 2A (Mackintosh et al. 1990; Falconer and Humpage 1996). These toxins are highly water-soluble and resistant to boiling, and thus pose a threat to water and food quality if not properly monitored (Falconer and Humpage 2005). More than $80 \%$ of the non-covalently bound MCYST in the zooplankton Bosmina $\mathrm{sp}$. fed to the sunfish Lepomis gibbosus was directly transferred to the sunfish, indicating that free or conjugated MCYST-LR can travel efficiently up the aquatic food web (Smith and Haney 2006).

Smith and Haney (2006) found that cyanobacterial toxins can be biomagnified across the food chain from lower to higher trophic levels, suggesting potential risk posed to human and/or higher vertebrates upon consumption of aquatic biota containing cyanobacteria toxin. Guidelines developed by the World Health Organization (WHO) to minimise the risk for human intoxication is based on toxicological studies in mice and expressed as the tolerable daily intake (TDI) of $0.04 \mu \mathrm{g}$ microcystin $\mathrm{kg}^{-1}$ body weight $\mathrm{d}^{-1}$ (Chorus and Bartram 1999). Based on the MCYSTs and their toxicity, the WHO guideline for MCYST-LR equivalent, the most commonly known and most toxic type of MCYST, in drinking water is $1 \mathrm{\mu g} \mathrm{I}^{-1}$ (Falconer et al. 1994). In recent studies (Chen et al. 2009; Zhang et al. 2009a) the presence of MCYSTs was indicated in serum of a chronically exposed human population, fishermen at Lake Chaohu, China, together with signs of hepatocellular damage. Humans usually do not consume high doses of MCYSTs to such an extent that lethal acute effects occur, but are rather exposed to chronic low doses in drinking water. However, only a few studies have tracked the presence of MCYSTs in single or multiple components of aquatic food webs (Kotak et al. 1996; Magalhães et al. 2001, 2003; Babcock-Jackson et al. 2002; Ibelings et al. 2005). Other studies have analysed the uptake of MCYSTs by aquatic organisms in an experimental setting, among others, zooplankton (DeMott 1999; Thostrup and Christoffersen 1999; Rohrlack et al. 2001; Schmidt et al. 2013).

The accumulation of MCYSTs in fish tissues is considered to be the most common and most important potential route of their exposure to humans (Oberholster et al. 2004, 2005). A few ecological studies investigated the environmental role of these toxins on fish. However, from the literature it is evident that the adverse effects of toxic cyanobacteria on 
indigenous fish species and their responses to cyanotoxins, mainly on sublethal or chronic exposure situations in Africa, have not been studied. Magalhães et al. (2001) showed that MCYSTs accumulate in the liver and muscle tissue of planktivorous Tilapia, particularly during Microcystis bloom events. They highlighted that the regular consumption of MCYSTs by fish would exceed the WHO TDI limit and therefore present a potential risk for fish consumers. Because Tilapia species are abundant in Africa, and are largely planktivorous and consume cyanobacteria, one might speculate that the consumption of Tilapia flesh would pose serious adverse health effects for people consuming it (Bennett and Thorpe 2008).

Loskop Dam is considered to be eutrophic to hypertrophic due to pollution by mankind, such as nutrient enrichment by partially treated or untreated sewage water in the upper river catchment, causing ongoing degradation of water quality resulting in the loss of aquatic biota (Oberholster and Botha 2011). Water enriched with nutrients may lead to several water quality discrepancies that may arise from the accumulation of nuisance growth of cyanobacteria and filamentous algae (van Ginkel 2004; Oberholster et al. 2012). The effects of blooms of these algae are the depletion in dissolved oxygen, decline in fish and zooplankton population, and excessive production of cyanotoxins.

The aim of this study was to determine MCYST-LR equivalent concentrations in selected fish tissues at Loskop Dam during a decomposing Microcystis bloom.

\section{Materials and methods}

\section{Study site}

Loskop Dam (2526'57.05" S, 29¹9'44.36" E) is a eutrophic to hypertrophic dam in Mpumalanga province, South Africa, with its main water supply coming from the upper Olifants River catchment (Figure 1), which flows through a confined $10 \mathrm{~km}$ gorge before entering Loskop Dam.

The reservoir has a surface area of $24.27 \mathrm{~km}^{2}$ and a volume of $374.3 \times 10^{3} \mathrm{~m}^{3}$ at full supply capacity, and was designed primarily to supply water for irrigated agriculture downstream of the dam wall (DWAF 2004). The total catchment area that drains into Loskop Dam is $11.464 \mathrm{~km}^{2}$. Over the past 15 years Loskop Dam has had a history of isolated incidents of fish mortality (Oberholster et al. 2010). These incidents have escalated during the past five years and are linked with crocodile mortalities and a population decline from \pm 80 animals to a total of six in 2008 (Oberholster et al. 2010). The Microcystis bloom started to develop in November 2011 (early summer) in the riverine zone of Loskop Dam when the cell count was $1.1 \times 10^{1}$ cells $\mathrm{I}^{-1}$. During late January 2012 the bloom reached a cell count of $1.3 \times 10^{7}$ cells $\left.\right|^{-1}$, after which the cell counts started to decline reaching $1.5 \times 10^{2}$ cells ${ }^{-1}$ in May 2012 (autumn).

\section{Physico-chemical parameters}

One sampling site was selected in each of the three zones of the dam (Figure 1). Dissolved oxygen, water temperature, $\mathrm{pH}$ and electrical conductivity values were measured in situ at the water surface at each site, using a Hach sensION ${ }^{\mathrm{TM}} 156$ portable multiparameter instrument (Loveland, USA). Water samples were taken with a
Van Dorn sampler and filtered through $0.45 \mu \mathrm{m}$ pore size Whatman GF/filters after which it was stored in polyethylene bottles ( 1 litre) that had been pre-rinsed with dilute sulphuric acid ( $\mathrm{pH}$ 2.0) for analysis of dissolved nutrients. All analyses were carried out according to standard methods (APHA, AWWA and WEF 1992). Chlorophyll a (Chl a) was extracted from lyophilised Whatman GF filters using $\mathrm{N}, \mathrm{N}$-dimethylformamide for $2 \mathrm{~h}$ at room temperature and measured spectrophotometrically at $647 \mathrm{~nm}$ and $664 \mathrm{~nm}$ according to Porra et al. (1989). Water transparency was measured with a $25 \mathrm{~cm}$ Secchi disc.

\section{Phytoplankton sampling}

At each site, water samples were collected at 1 and $3 \mathrm{~m}$ using a Van Dorn sampler and pooled to form one integrated sample. One litre of the integrated sample was preserved in the field with Lugol's solution for phytoplankton identification, while the rest was used for chemical analyses and determination of MCYST-LR equivalent toxicity. The water samples were kept cool and in the dark during the $3 \mathrm{~h}$ period of transfer from the field to the laboratory. All algal identifications were done with a compound microscope at $1250 \times$ magnification, after van Vuuren et al. (2006) and Taylor et al. (2007). Strip counts were made until at least 300 individuals of each of the dominant phytoplankton species had been counted. The relative abundance of phytoplankton taxa at each sampling site was categorised according to Hörnström (1999).

\section{ELISA assays of water}

For the determination of extracellar MCYST-LR equivalent concentrations at the three sampling sites, one litre of the integrated water sample was poured gently through a $934 \mathrm{AH}$ glass fibre filter in the field, after which the filtered water was stored on dry ice and returned to the laboratory for toxin analysis. The filtered water was applied directly to the enzyme-linked immunosorbent assay (ELISA) using PowerWave HT microplate spectrophotometer (Biotek, Winooski, USA) in the laboratory to determine extracellular MCYST-LR equivalent levels using the ELISA assay (Mitsoura et al. 2013). The ELISA assay was conducted with a Quanti-Kit for microcystins (EnviroLogix, USA).

\section{ELISA assays of liver and muscle}

Twenty Labeo rosae and six Oreochromis mossambicus were caught using $120 \mathrm{~mm}$ stretched mesh gillnets set near each sampling site in May 2012. These fish species were chosen due to their omnivorous feeding habits. From each fish caught, length and body weight were recorded and the fish was then sacrificed by severing the spinal cord just behind the head, before dissection of the different tissues. Tissues were kept frozen at $-80^{\circ} \mathrm{C}$ until the extraction procedure was undertaken to determine MCYST-LR equivalent.

MCYSTs were extracted from the tissues of fish with $100 \%$ methanol after Magalhães et al. (2001), stirred overnight at room temperature and then centrifuged at $1300 \times g$ for $15 \mathrm{~min}$ in a Universal 32 centrifuge. The supernatant was collected and stored overnight at $4{ }^{\circ} \mathrm{C}$. The supernatant was transferred into new Eppendorf tubes and kept on ice until protein concentration was determined using 


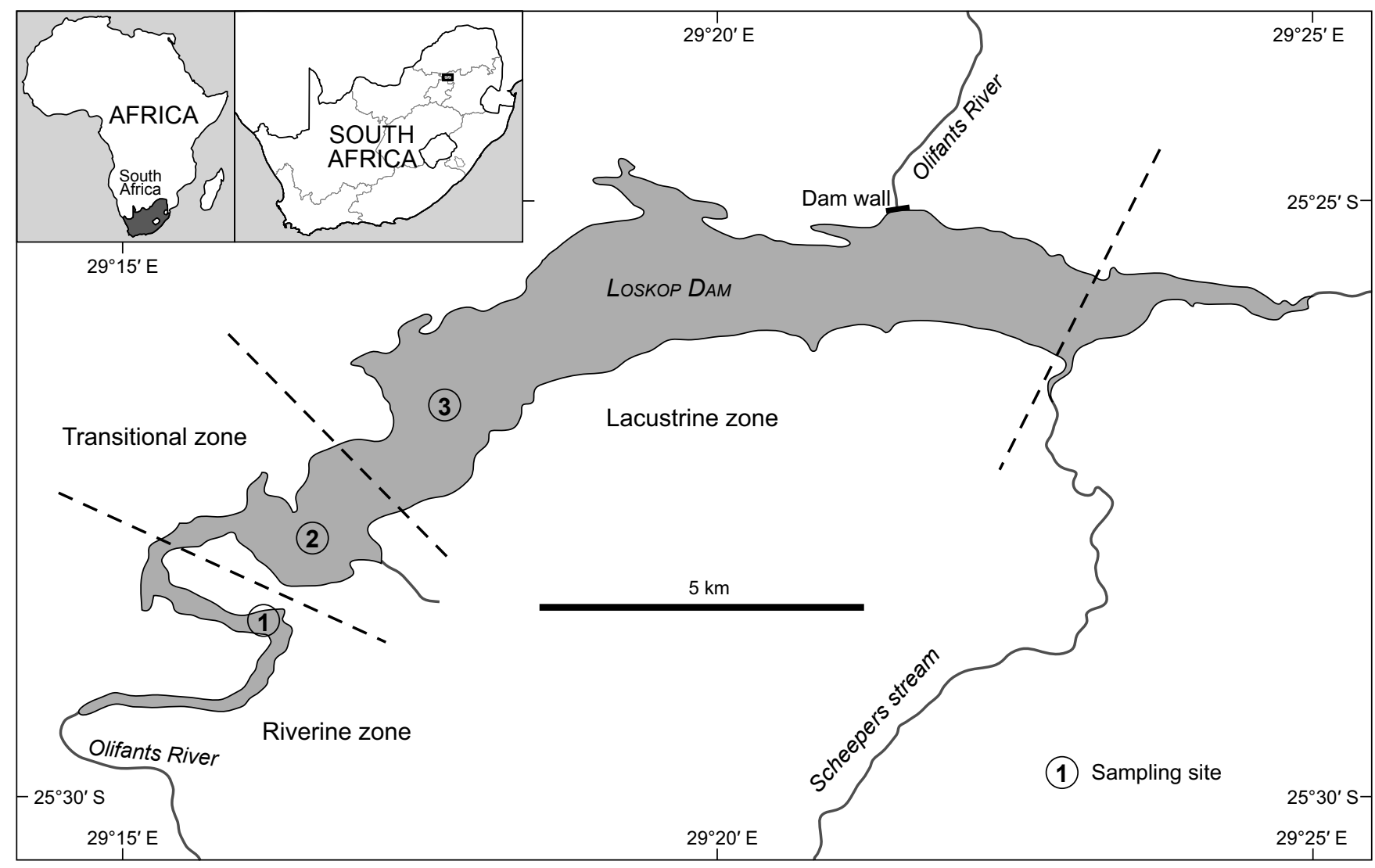

Figure 1: Map of Loskop Dam, Mpumalanga province, South Africa, showing locations of sampling sites (modified after Oberholster et al. 2010)

Nanodrop (Nanodrop ND-1000). One mg of protein from each sample (liver or muscle) was used. These samples were analysed by the ELISA method using microcystin plate kits (Envirologix Inc. ${ }^{\circledR}$ ). Each sample was analysed in triplicate and MCYST values were expressed as MCYST-LR equivalents (Magalhães et al. 2001).

The concentrations of MCYST-LR equivalent were expressed in nanogrammes (ng) of MCYST-LR equivalent per gramme of liver and muscle tissue. These data were compared with concentrations from rat tissues of the WHO provisional standards.

\section{Stomach contents}

The stomach was dissected from each fish specimen and the stomach content of each fish was fixed with $4 \%$ formaldehyde for microscopic examination of phytoplankton content and abundance according to Oberholster et al. (2012).

\section{Statistical analysis}

Subsequent multiple comparisons were done with the Tukey post hoc test at $p<0.05$ to compare different mean phytoplankton species abundances between sampling sites. All statistical calculations were done with the statistical package SPSS v 21.0 (SPSS Inc., Chicago). The Berger-Parker dominance index (Berger and Parker 1970) was used to estimate the dominance of organisms at each sampling site.

\section{Results}

\section{Physical and chemical parameters}

The more acidic $\mathrm{pH}$ value (6.49) of the water at Site 3 in the lacustrine zone of Loskop Dam differed notably from the alkaline values of 9.76 recorded in the riverine zone and of 8.64 in the transitional zone of the dam during May 2012 (Table 1). Nutrient ratios of TN to TP were 1:13 at Site $1,1: 28$ at Site 2 , and $1: 26$ at Site 3 , indicating that the area within the riverine zone was eutrophic according to the Forsberg and Ryding (1980) index. Surface water electrical conductivity values varied between $613 \mu \mathrm{S} \mathrm{cm}{ }^{-1}$ at Site 1 and $446 \mu \mathrm{S} \mathrm{cm}^{-1}$ at Site 3 (Table 1). The average surface water temperature was $22.5^{\circ} \mathrm{C}$, while Secchi disc measurements fluctuated between $0.50 \mathrm{~m}$ at the riverine zone sampling site and $2.63 \mathrm{~m}$ at Site 3 in the lacustrine zone. The transitional and lacustrine zones were found to be oligotrophic, with more or less the same concentration of total phosphates, whereas the riverine zone was hypertrophic with $0.2 \mathrm{mg} \mathrm{l}^{-1}$ of phosphorus (Table 1) and $0.15 \mathrm{mg} \mathrm{l}^{-1}$ of chlorophyll a (Figure 2).

\section{Phytoplankton assemblage}

The dominant diatom species at Site 1 in the riverine zone (Berger-Parker index 0.213) was Melosira varians (Agardh) with an average biovolume of $4.2 \mathrm{~mm}^{3} \mathrm{I}^{-1}$, while the cyanobacterium Microcystis aeruginosa (Kützing) was present at a much higher biovolume on $13 \mathrm{~mm}^{3} \mathrm{I}^{-1}$. The 
Table 1: Physico-chemical water quality in the three zones of Loskop Dam in May 2012

\begin{tabular}{lccc}
\hline Parameter & Riverine & Transitional & Lacustrine \\
\hline $\mathrm{pH}$ & 9.76 & 8.64 & 6.49 \\
Conductivity $\left(\mu \mathrm{S} \mathrm{cm}^{-1}\right)$ & 613 & 463 & 446 \\
Dissolved oxygen $(\%)$ & 26.5 & 23.3 & 21.3 \\
Secchi disc $(\mathrm{m})$ & 0.50 & 0.81 & 2.63 \\
TDS & 371.8 & 266.5 & 271.05 \\
Bicarbonate $\left(\mathrm{mg} \mathrm{l}^{-1}\right)$ & 40 & 37 & 32 \\
Carbonate $\left(\mathrm{mg} \mathrm{l}^{-1}\right)$ & 30 & 24 & 28 \\
$\mathrm{TN}\left(\mathrm{mg} \mathrm{l}^{-1}\right)$ & 2.6 & 1.4 & 1.3 \\
$\mathrm{NH}_{4}\left(\mathrm{mg} \mathrm{l}^{-1}\right)$ & 0.24 & 0.1 & 0.21 \\
$\mathrm{NO}_{3}\left(\mathrm{mg} \mathrm{l}^{-1}\right)$ & 0.66 & 0.8 & 0.60 \\
$\mathrm{TP}\left(\mathrm{mg} \mathrm{l}^{-1}\right)$ & 0.2 & 0.05 & 0.03 \\
$\mathrm{Silica}\left(\mathrm{mg} \mathrm{l}^{-1}\right)$ & 0.2 & 3.4 & 3.9 \\
\hline
\end{tabular}

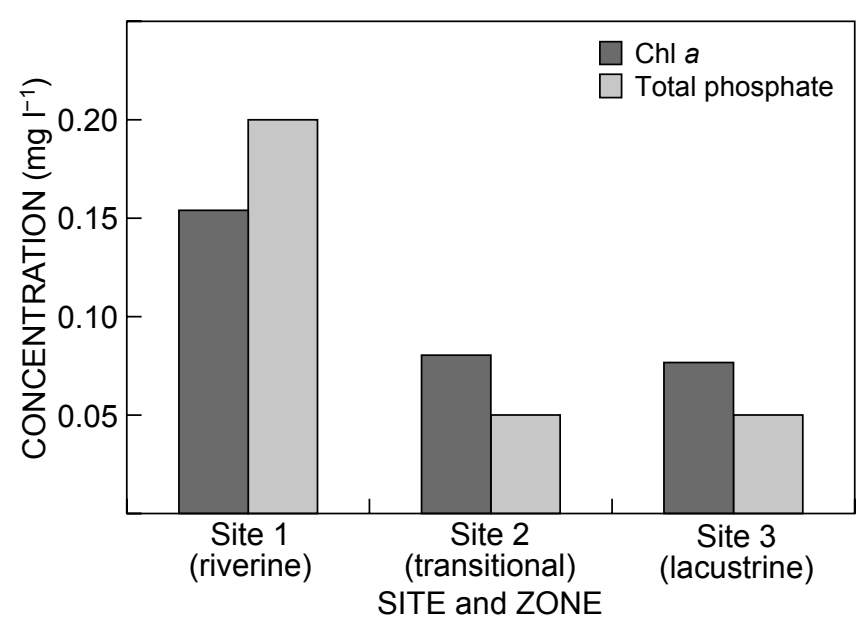

Figure 2: Chlorophyll a $(\mathrm{Chl} \mathrm{a})$ content and total phosphate at three sites in Loskop Dam in May 2012

dominant (Berger-Parker index 0.463) cyanobacterium $M$. aeruginosa at Site 1 was totally absent at Site 3 and therefore was not a contributing factor to the extracellular MCYST-LR equivalent concentrations in the water column at Site 3 (Figure 3). The highest concentration of extracellular MCYST-LR equivalent, $3.25 \mathrm{\mu g} \mathrm{I}^{-1}$, was observed at Site 1 , this being 3.25 times higher than the WHO standard, but was not significantly $(p>0.05)$ higher in comparison to that at Sites 2 and 3.

The higher cell counts of $M$. aeruginosa at Site 1 correlated significantly $(p<0.05)$ with the higher total phosphorus concentrations on $0.2 \mu \mathrm{g} \mathrm{I}^{-1}$ at this site (Table 1). The diatom Craticula cuspidata (Kützing) also occurred at a low biovolume $\left(1.9 \mathrm{~mm}^{3} \mathrm{I}^{-1}\right)$ at Site 1 (Table 2). The latter is a good indicator of eutrophic water conditions and may tolerate critical to very heavy pollution, according to Taylor et al. (2007).

The dominant phytoplankton species that formed a bloom in the transitional and main basin zones of Loskop Dam throughout the year was the larger and slowergrowing species Ceratium hirundinella (Müller). During May 2012 it had an average biovolume of $14 \mathrm{~mm}^{3} \mathrm{I}^{-1}$, which correlated positively $(p<0.05)$ with the higher average $\mathrm{Si}$

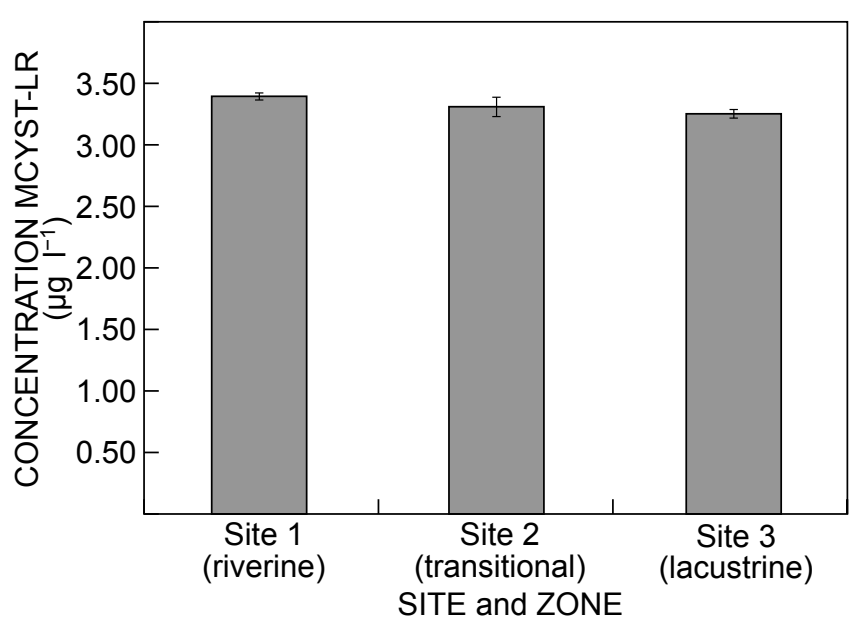

Figure 3: Extracellular microcystin-LR concentrations in water column at three sites in Loskop Dam. Error bars indicate SD; $p>$ 0.05

concentrations of 3.4 and $3.9 \mathrm{mg} \mathrm{l}^{-1}$ in the water column at Sites 2 and 3 , in comparison with lower concentrations of $0.2 \mathrm{mg} \mathrm{l}^{-1}$ at Site 1 in the riverine zone (Tables 1 and 2).

\section{Comparative studies of fish}

The total body weight and body length of $L$. rosae and $O$. mossambicus are summarised in Figure 4 . The overall total number of fish for the study was 26 . Most $L$. rosae were smaller in weight, with a minimum mass of $708 \mathrm{~g}$ and length of $37 \mathrm{~cm}$ in comparison to O. mossambicus with a minimum mass of $1437.9 \mathrm{~g}$ and length of $39.2 \mathrm{~cm}$. Of the 26 fish sampled nine $L$. rosae were females and 11 males, whilst no male $O$. mossambicus were recorded. Males were bigger than females with respect to weight and length.

Stomach contents of both species were analysed microscopically to determine their main diet (Figure 5). Very little $(<5 \%$ of total stomach content) cyanobaterial cells (Microcystis aeruginosa) was consumed orally in comparison to Ceratium hirundinella that made up $25-53 \%$ of the total stomach content of the two different fish species.

\section{Detection of microcystin-LR equivalent in fish}

Of the 26 fish examined more than $80 \%$ had average MCYST-LR equivalent concentrations above the WHO TDI level of $0.04 \mu \mathrm{g} \mathrm{kg}^{-1}$ body weight $\mathrm{d}^{-1}$ (Chorus and Bartram

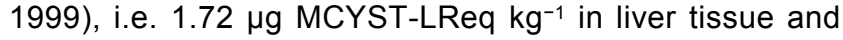
$0.19 \mu \mathrm{g} \mathrm{MCYST-LReq} \mathrm{kg}^{-1}$ in muscle tissue for $L$. rosae, and $2.14 \mu \mathrm{g} \mathrm{MCYST-LReq} \mathrm{kg}^{-1}$ in liver tissue and $0.17 \mu \mathrm{g}$ MCYST-LReq $\mathrm{kg}^{-1}$ in muscle tissue for $O$. mossambicus, which means that the daily consumption of fish by humans could be higher than the safety value. All $L$. rosae had significantly lower concentration in the liver as compared to O. mossambicus caught from the same site (Figure 6).

There was a significant difference $(p<0.05)$ in MCYST-LR equivalent concentration found in liver and muscle tissue between the two fish species but no significant differences $(p>0.73)$ between the sexes (result not shown). High concentrations of MCYST-LR equivalent in the liver and muscle tissue from both species were detected and 
Table 2: Algal community compositions at 1 and $3 \mathrm{~m}$ depths at three sites in Loskop Dam during a decomposed cyanobacterial bloom in May $2012 .+=$ rare $\left(\leq 50\right.$ cells $\left.\left.\right|^{-1}\right) ;++=$ scarce $\left(51-250\right.$ cells $\left.{ }^{-1}\right) ;+++=$ common $\left(251-1000\right.$ cells $\left.\left.\right|^{-1}\right) ;++++=$ abundant $(1001-5000$ cells $\left.\mathrm{I}^{-1}\right)$; and $+++++=$ predominant $\left(\geq 5001\right.$ cells $\left.\mathrm{I}^{-1}\right)$

\begin{tabular}{|c|c|c|c|c|c|c|c|}
\hline \multirow{2}{*}{ Phylum/Class } & \multirow{2}{*}{ Major species } & \multicolumn{2}{|c|}{ Site 1} & \multicolumn{2}{|c|}{ Site 2} & \multicolumn{2}{|c|}{ Site 3} \\
\hline & & $1 \mathrm{~m}$ & $3 \mathrm{~m}$ & $1 \mathrm{~m}$ & $3 \mathrm{~m}$ & $1 \mathrm{~m}$ & $3 \mathrm{~m}$ \\
\hline \multicolumn{8}{|l|}{ Cryptophyta } \\
\hline Cryptophyceae & Cryptomonas marsonii (Ehrenberg) & + & + & & & & \\
\hline \multicolumn{8}{|l|}{ Chrysophyta } \\
\hline Chrysophyceae & Dinobryon divergens (Ehrenberg) & + & + & & & & \\
\hline \multicolumn{8}{|l|}{ Bacillariophyta } \\
\hline \multirow[t]{14}{*}{ Bacillariophyceae } & Aulacoseira muzzanensis (Meister) & + & & & & & \\
\hline & Diatoma vulgaris (Bory) & ++ & & & & & \\
\hline & Craticula cuspidata (Kützing) & + & & + & + & & \\
\hline & Fragilaria ulna (Nitzch) & + & & & & + & + \\
\hline & Pinnularia viridis (Nitzch) & + & & & & & \\
\hline & Synedra acus (Kützing) & & & & & & \\
\hline & Melosira varians (Agardh) & ++ & ++ & & ++ & & \\
\hline & Fragilaria capucina (Desmaziéres) & + & & + & & & \\
\hline & Gyrosigma rautenbachiae (Cholnoky) & + & & & & & \\
\hline & Aulacoseira granulata (Ehrenberg) & ++ & + & & + & + & \\
\hline & Nitzschia palea (Kützing) & + & & & & & \\
\hline & Staurosira elliptica (Schumann) & & & & + & & + \\
\hline & Asterionella formosa (Hassall) & + & & & + & & \\
\hline & Fragilaria crotonensis (Kitton) & & & ++++ & ++++ & ++ & + \\
\hline \multicolumn{8}{|l|}{ Dinophyta } \\
\hline \multirow[t]{2}{*}{ Dinophyceae } & Peridium africana (Ehrenberg) & + & + & +++ & +++ & + & \\
\hline & Ceratium hirundinella (Müller) & & & ++++ & ++++ & ++ & + \\
\hline \multicolumn{8}{|l|}{ Chlorophyta } \\
\hline \multirow[t]{7}{*}{ Chlorophyceae } & Closterium lineatum (Nitzch) & + & & & & + & + \\
\hline & Pediastrum duplex (Meyer) & + & & + & & & \\
\hline & Cosmarium pseudo praemorsum (Corda) & & & & & ++ & ++ \\
\hline & Oocystis rupestris (Braun) & & & & & ++ & \\
\hline & Scenedesmus quadricauda (Meyer) & + & + & & & + & + \\
\hline & Cladophora glomerata (Kützing) & + & + & & & & \\
\hline & Spirogyra reinhardi (Kützing) & + & & & & & \\
\hline \multicolumn{8}{|l|}{ Euglenophyta } \\
\hline \multirow[t]{3}{*}{ Euglenophyceae } & Trachelomonas intermedia (Ehrenberg) & ++ & + & ++ & & + & + \\
\hline & Phacus pleuronectes (Dujardin) & & & & + & & \\
\hline & Euglena sociabilis (Bold) & & & & + & & \\
\hline \multicolumn{8}{|l|}{ Cyanophyta } \\
\hline \multirow[t]{2}{*}{ Cyanophyceae } & Microcystis aeruginosa (Kützing) & +++ & +++ & + & & & \\
\hline & Oscillatoria tenuis (Vaucher) & + & & + & & & \\
\hline
\end{tabular}
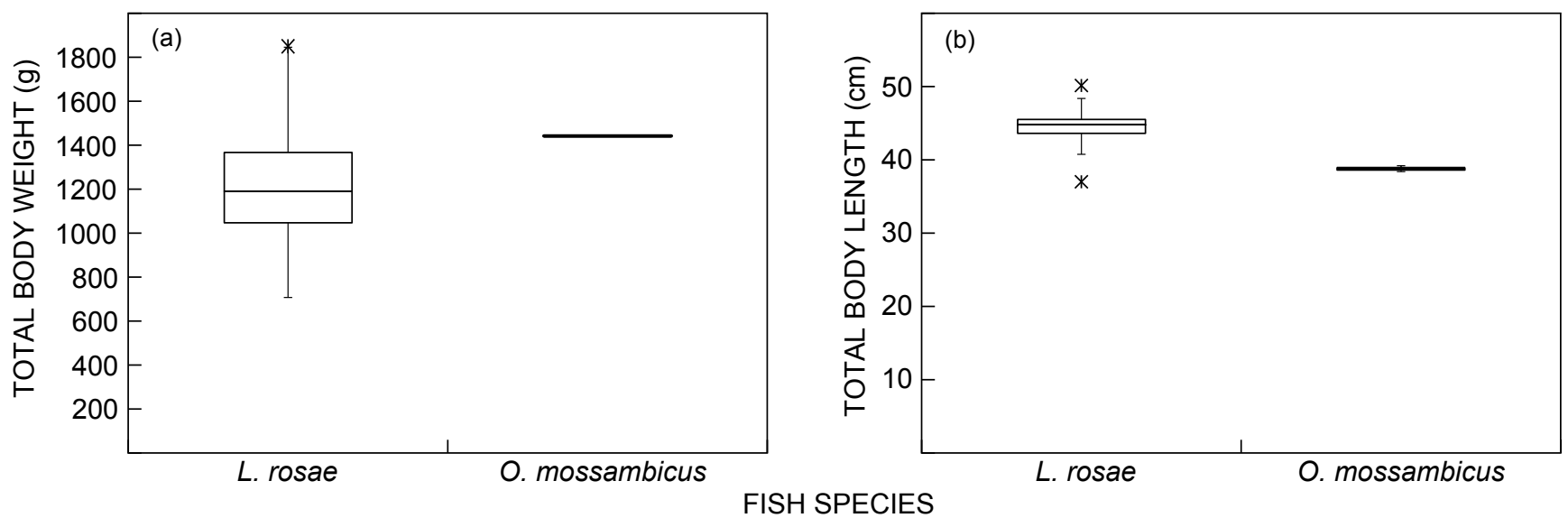

Figure 4: Box plots of (a) weight and (b) total length of Labeo rosae and Oreochromis mossambicus in Loskop Dam in May 2012. Error bars indicate SD; stars indicate outliers; $p<0.05$ 


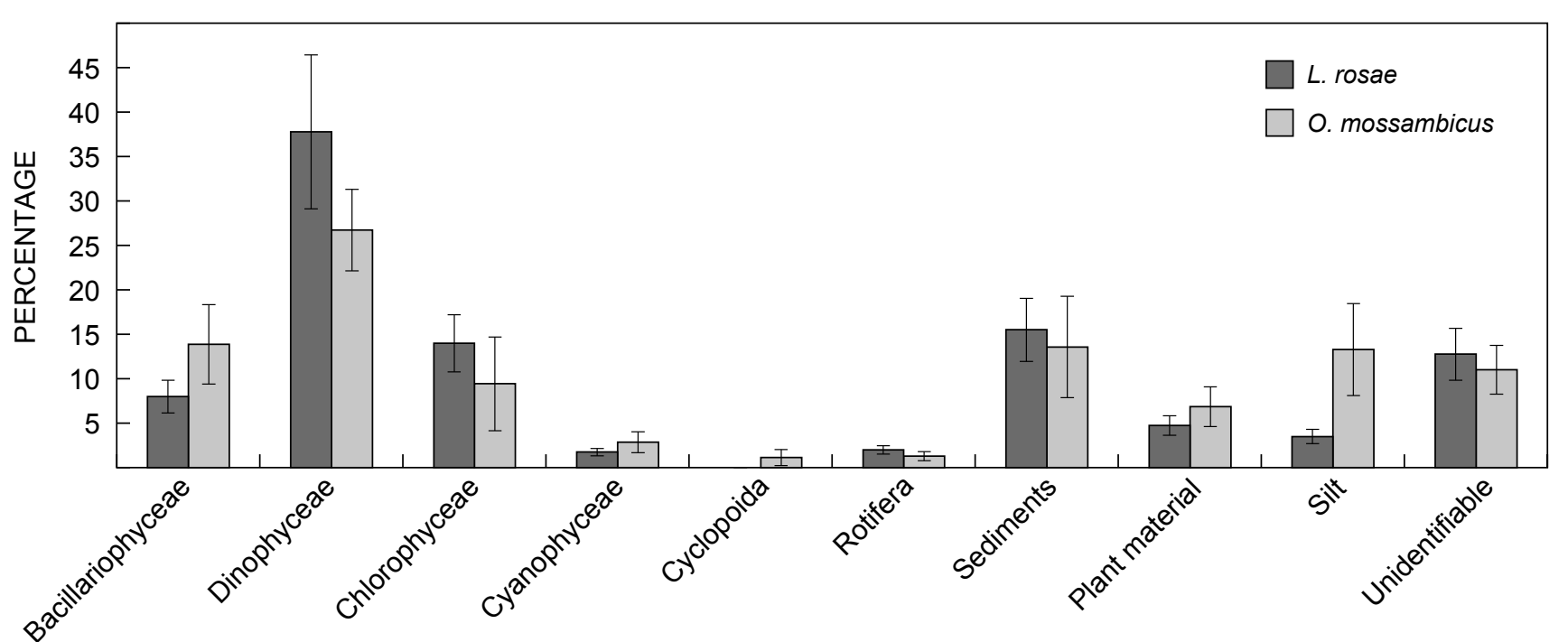

STOMACH CONTENTS

Figure 5: Biotic and abiotic stomach contents of Labeo rosae and Oreochromis mossambicus from Loskop Dam in May 2012. Error bars indicate $\mathrm{SD} ; p<0.05$

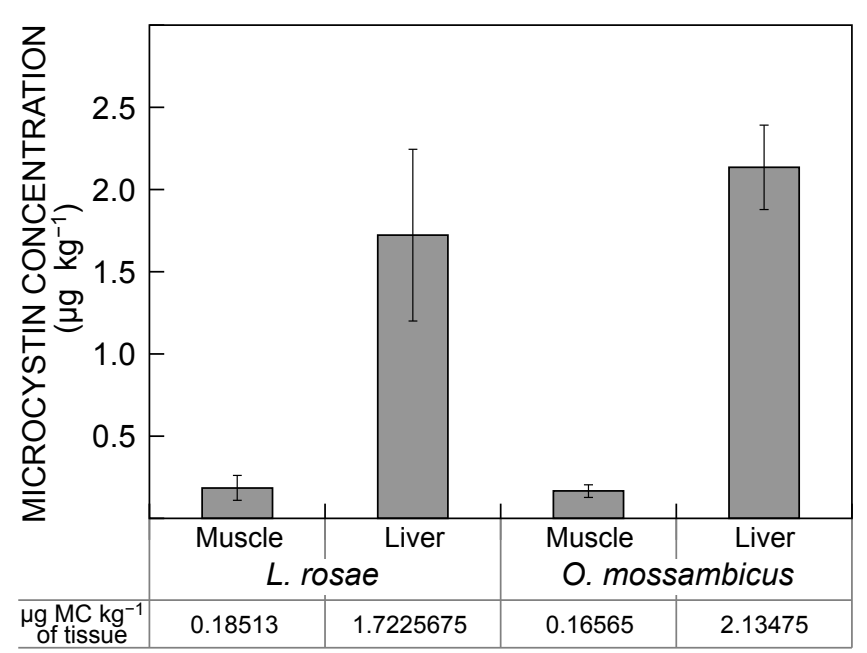

Figure 6: Mean microcystin-LR concentrations in muscle and liver tissue of Labeo rosae and Oreochromis mossambicus from Loskop Dam in May 2012. Error bars indicate SD; $p<0.05$

consumption of adequate fish biomass ( $<0.04 \mu \mathrm{g} \mathrm{kg}^{-1}$ body) of these tissues might cause severe acute effects.

The MCYST-LReq concentrations in liver and muscle tissue for $L$. rosae were 43.6 times and 4.6 times higher, respectively, than the WHO guidelines. The MCYST-LReq concentrations in liver and muscle tissue for 0 . mossambicus were 53.4 times and 4.1 times higher than WHO guidelines. The low concentrations of cyanobacteria cells detected in the stomach content of both fish species may have played a minor role, and the bioaccumulation of cyanotoxin MCYST-LR equivalent in the fish organs may have occurred through the intake of water containing extracellular MCYST-LR equivalent, or from consuming prey that had indigested toxic cyanobacterial cells.

\section{Discussion}

High MCYST concentrations pose a health hazard to aquatic life, humans and wildlife (Oberholster et al. 2009). This suggests that biomagnification of MCYSTs in aquatic food chains may be another important factor, suggesting a potential risk for higher trophic level species. Epidemiological investigations showed that the consumption of water contaminated with MCYSTs poses many adverse health effects such as the promotion of liver cancer, gastrointestinal diseases and spleen diseases as well as DNA fragmentation (Zhou et al. 2002; Oberholster et al. 2004). It was evident that fish were exposed to MCYSTs in the water column, even though the intake of cyanobacteria cells was minimal via ingestion (Figure 5). However, it cannot be ruled out that exposure to MCYSTs may have been contributed by prey such as zooplankton that had fed on cyanobacteria (Malbrouck and Kestemont 2006). In the present study, zooplankton was detected only in very low numbers in the stomach content of both fish species.

The concentrations of MCYST-LR equivalent were much higher in the liver tissue than in the muscle tissue and could possibly be related to the functions of the different tissues. The liver serves as a detoxifying organ of the body and therefore it is exposed to high loads of different toxins. The liver also contains more fatty tissue, a target tissue for MCYSTs, than muscle tissue.

These higher MCYST-LR equivalent concentrations in fish tissues correspond with high concentrations of extracelIular MCYST-LR equivalent recorded in the water column, suggesting that toxin accumulation may be either through bioconcentration and/or biomagnification. This is supported by the results from the stomach content analysis where $M$. aeruginosa was present in very low numbers. Significant concentrations of MCYSTs were found in the water and in both fish species. Cyanotoxins could be accumulated in 
animals through the food chain, causing health problems even to humans (Vasconcelos 2006). Nonetheless, Microcystis blooms can be highly localised (Andersen 1997, 2004) and it is likely these fish were exposed to high extracellular concentrations of MCYSTs at Sites 2 and 3 where few or no cyanobacterial cells were observed in the water column. In the present study we did not correlate the internal MCYST-LR equivalent concentrations of the cyanobacterial cells of the bloom with the extracellular MCYST-LR equivalent concentrations, since few or no cyanobacterial cells were observed in the water column at Sites 2 and 3, where $70 \%$ of the fish under study were captured.

Regarding the risk to humans, estimated daily intake (EDI) estimation would be necessary before the measured concentrations of MCYSTs in the fish tissue samples could be compared to the WHO TDI provisional guidelines. At the levels found in $L$. rosae in our study, the calculated EDI in liver was 46.6 times higher, and in muscle 4.6 times higher, than the advisable TDI value on $0.04 \mu \mathrm{g} \mathrm{kg}^{-1}$ of body weight. In O. mossambicus from the current study the calculated EDI in liver was 53.4 times higher, and in muscle 4.1 times higher, than the advisable TDI value. Therefore, both fish species from Loskop Dam could possibly pose a health hazard and they are thus not safe for human consumption. In addition, according to Soares et al. (2004), cyanobacterial toxins could still be found in fish muscle several days after the end of a toxic bloom.

Only the uptake of MCYSTs from aquatic organisms was used to evaluate exposure risk of humans to MCYSTs in Loskop Dam. A possible human health hazard that needs further investigation is the influence of extracellular concentrations of MCYST-LR equivalent on the irrigated crops produced on the second largest irrigation scheme in South Africa downstream of Loskop Dam. Secondary metabolites can accumulate in the tissue of plants irrigated with contaminated water, as previously highlighted by Codd (1999) who stated that single cells of $M$. aeruginosa and the hepatotoxin MCYST were retained on salad lettuce after being sprayed with irrigation water containing MCYST-producing cyanobacteria. Therefore, extracellular chronic toxic effects to humans from exposure through drinking water or contaminated food are probable, especially if there is long-term frequent exposure (Magalhães et al. 2001, 2003; Zhang et al. 2009b).

Acknowledgements - The study was funded by the National Research Foundation (NRF; TTK2006062100013); Council for Scientific and Industrial Research; Department of Genetics, University of Stellenbosch; and the Department of Biodiversity, University of Limpopo. We thank the Belgian Vlaamse Interuniversitaire Raad University Development Cooperation funding programme for additional funding. Tshepiso Ramalepe and Charles Nyalungu, University of Limpopo, are thanked for assistance during fieldwork.

\section{References}

American Public Health Association (APHA), American Water Works Association (AWWA) and Water Environment Federation (WEF). 1992. Standard methods for the examination of water and wastewater (19th edn). Washington, DC: APHA, AWWA and WEF.
Anderson DM. 1997. Bloom dynamics of toxic Alexandrium species in the north-eastern United States. Limnology and Oceanography 42: 1009-1022.

Anderson DM. 2004. Prevention, control, and mitigation of harmful algal blooms: multiple approaches to $\mathrm{HAB}$ management. In: Hudnell HK, Etheridge S, Anderson D, Kleindinst J, Zhu M, Zou Y (eds), Harmful algae management and mitigation. Singapore: Asia Pacific Economic Cooperation. pp 123-130.

Babcock-Jackson L, Carmichael WW, Culver DA. 2002. Dreissenid mussels increase exposure of benthic and pelagic organisms to toxic microcystins. Verhandlungen des Internationalen Verein Limnologie 28: 1082-1085.

Bennett E, Thorpe A. 2008. Review of river fisheries valuation in Central and South America. In: Neiland AE, Béné C (eds), Tropical river fisheries valuation: background papers to a global synthesis. The WorldFish Center Studies and Reviews 1836. Penang: The WorldFish Center. pp 1-46.

Berger WH, Parker FL. 1970. Diversity of planktonic foraminifera in deep sea sediments. Science 168: 1345-1347.

Chen J, Xie P, Li L, Xu J. 2009. First identification of the hepatotoxic microcystins in the serum of a chronically exposed human population, together with indication of hepatocellular damage. Toxicological Sciences 108: 81-89.

Chorus I, Bartram J. 1999. Toxic cyanobacteria in water: a guide to their public health consequences, monitoring and management. London: E \& FN Spon, on behalf of the WHO.

Codd GA. 1999. Cyanobacterial toxins: their occurrence in aquatic environments and significance to health. In: Charpy $P$, Larkum AWD (eds), Marine cyanobacteria. Bulletin de l'Institut Oceanographique, Monaco 19: 483-500.

DeMott WR. 1999. Foraging strategies and growth inhibition in five daphnids feeding on mixtures of a toxic cyanobacterium and green alga. Freshwater Biology 42: 263-274.

DWAF (Department of Water and Forestry). 2004. Olifants Water Management Area: internal strategic perspective. Report PWMA 04/0000/00/0304. DWAF, Pretoria.

Falconer IR, Burch MD, Steffensen DA, Choice M, Coverdale OR. 1994. Toxicity of the blue-green algae (cyanobacterium) Microcystis aeruginosa in drinking water to growing pigs, as an animal model for human injury and risk assessment. Environmental Toxicology and Water Quality 9: 131-139.

Falconer IR, Humpage AR. 1996. Tumour promotion by cyanobacterial toxins. Phycologia 35: 74-79.

Falconer IR, Humpage AR. 2005. Health risk assessment of cyanobacterial (blue-green algal) toxins in drinking water. International Journal of Environmental Research and Public Health 2: 43-50.

Forsberg CG, Ryding SO. 1980. Eutrophication. Parameters and trophic state indices in 30 Swedish waste water receiving lakes. Hydrobiologia 89: 189-207.

Hörnström E. 1999. Long-term phytoplankton changes in acid and limed lakes in SW Sweden. Hydrobiologia 394: 93-102.

Ibelings BW, Bruning $\mathrm{K}$, de Jonge $\mathrm{J}$, Wolfstein $\mathrm{K}$, Dionisio PLM, Postma J, Burger T. 2005. Distribution of microcystins in a lake foodweb: no evidence for biomagnification. Microbial Ecology 49: 487-500.

Kotak BJ, Semalulu S, Friytz DL, Prepas EE, Hrudey SE, Coppock RW. 1996. Hepatic and renal pathology of intraperitoneally administered microcystin-LR in rainbow trout (Oncorhynchus mykiss). Toxicon 34: 517-525.

Mackintosh C, Beattie KA, Klumpp S, Cohen P, Codd GA. 1990. Cyanobacterial microcystin-LR equivalent is a potent and specific inhibitor of protein phosphatases 1 and $2 \mathrm{~A}$ from both mammals and higher plants. FEBS Letters 264: 187-192.

Magalhães VF, Marinho MM, Domingos P, Oliveira AC, Costa SM, Azevedo LO, Azevedo SM. 2003. Microcystins (cyanobacteria hepatotoxins) bioaccumulation in fish and crustaceans from 
Sepetiba Bay (Brasil, RJ). Toxicon 42: 289-295.

Magalhães VFDE, Soares RM, Azevedo SMFO. 2001. Microcystin contamination in fish from the Jacarepagua Lagoon (Rio de Janeiro, Brazil): ecological implication and human health risk. Toxicon 39: 1077-1085.

Malbrouck C, Kestemont P. 2006. Effects of microcystins on fish. Environmental Toxicology and Chemistry 25: 72-86.

Mitsoura A, Kagalou I, Papaioannou N, Mente E, Papadimitrou T. 2013. The presence of microsystins in fish Cyprinus carpo tissue: a histopathological study. International Aquatic Research 13: 5-8.

Oberholster PJ. 2009. Impact on ecotourism by water pollution in the Olifants river catchment, South Africa. SIL News 55: 8-9.

Oberholster PJ, Botha A-M. 2011. Dynamics of phytoplankton and phytobenthos in Lake Loskop (South Africa) and downstream irrigation canals. Fundamental and Applied Limnology 179: 169-178.

Oberholster PJ, Botha A-M, Cloete TE. 2005. An overview of toxic freshwater cyanobacteria in South Africa, with special reference to risk, impact and detection by molecular marker tools. Biokemistri 17: 57-71.

Oberholster PJ, Botha A-M, Grobbelaar JU. 2004. Microcystis aeruginosa: source of toxic microcystins in drinking water. African Journal of Biotechnology 3: 159-168.

Oberholster PJ, Myburgh JG, Ashton PJ, Botha A-M. 2010. Responses of phytoplankton upon exposure to a mixture of acid mine drainage and high levels of nutrient pollution in Lake Loskop, South Africa. Ecotoxicology and Environmental Safety 73: 326-335.

Oberholster PJ, Myburgh JG, Ashton PJ, Coetzee JJ, Botha A-M. 2012. Bioaccumulation of aluminium and iron in the food chain of Lake Loskop, South Africa. Ecotoxicology and Environmental Safety 75: 134-141.

Oberholster PJ, Myburgh GJ, Govender D, Bengis R, Botha A-M. 2009. Identification of toxigenic Microcystis strains after incidents of wild animal mortalities in the Kruger National Park, South Africa. Ecotoxicology and Environmental Safety 12: 1177-1182.

Porra RJ, Thompson WA, Kriedemann PE. 1989. Determination of accurate extinction coefficients and simultaneous equations for assaying chlorophylls $a$ and $b$ extracted with four different solvents: verification of the concentration of chlorophyll standards by atomic absorption spectrometry. Biochimica et
Biophysica Acta 975: 384-394.

Rohrlack T, Dittman E, Borner T, Christoffersen K. 2001. Effects of cell-bound microcystins on survival and feeding of Daphnia spp. Applied and Environmental Microbiology 67: 3523-3529.

Schmidt JR, Shaskus M, Estenik JF, Oesch C, Khidekel R, Boyer GL. 2013. Variations in the microcystin content of different fish species collected from a eutrophic lake. Toxins (Basel) 5: 992-1009.

Soares RM, Magalhães VF, Azevedo SM. 2004. Accumulation and depuration of microcystins (cyanobacteria hepatotoxins) in Tilapia rendalli (Cichlidae) under laboratory conditions. Aquatic Toxicology 70: 1-10.

Smith JL, Haney JF. 2006. Foodweb transfer, accumulation, and depuration of microcystins, a cyanobacterial toxin, in pumpkinseed sunfish (Lepomis gibbosus). Toxicon 48: 580-589.

Taylor JC, Harding WR, Archibald CGM. 2007. An illustrated guide to some common diatom species from South Africa. WRC Report No. TT 282/07. Pretoria: Water Research Commission.

Thostrup L, Christoffersen K. 1999. Accumulation of microcystin in Daphnia magna feeding on toxic Microcystis. Archiv für Hydrobiologie 145: 447-467.

van Ginkel CE. 2004. A national survey of the incidence of cyanobacterial blooms and toxin production in major impoundments. Internal Report No. N/0000/00/DEQ/0503. Resource Quality Services, Department of Water Affairs and Forestry, Pretoria.

van Vuuren S, Taylor JC, Gerber A, van Ginkel C. 2006. Easy identification of the most common freshwater algae. Pretoria: North-West University and Department of Water Affairs and Forestry.

Vasconcelos VM. 2006. Eutrophication, toxic cyanobacteria and cyanotoxins: when ecosystems cry for help. Limnetica 25: $425-432$.

Zhang D, Xie P, Chen J. 2009b. Effects of temperature on the stability of microcystins in muscle of fish and its consequences for food safety. Bulletin of Environmental Contamination and Toxicology 84: 202-207.

Zhang D, Xie P, Liu Y, Qiu T. 2009a. Transfer, distribution and bioaccumulation of microcystins in the aquatic food web in Lake Taihu, China, with potential risks to human health. Science of the Total Environment 407: 2191-2199.

Zhou L, Yu H, Chen K. 2002. Relationship between microcystin in drinking water and colorectal cancer. Biomedical and Environmental Sciences 15: 166-171. 